\title{
Selvmordsmetoder i Norge - potensial for forebygging?
}

\author{
Ved Finn Gjertsen
}

\section{Hvordan kan rutinedata fra helseregistre brukes til å identifisere potensialet for å forebygge selumord som folkehelseproblem? Kan informasjon om valg av selumordsmetode, i tillegg til kjente risiko- faktorer, bidra til bedre målretting av tiltak?}

Reduksjon av selvmord og villet egenskade er implementert som helsepolitisk målsetting i en rekke land, inkludert Norge. En viktig bakgrunn for dette var Verdens helseorganisasjons 30. generalforsamling i 1977 som formulerte en overordnet helsepolitisk målsetting om helse for alle innen år 2000. Dette ble fulgt opp av helseorganisasjonens regionale komité for Europa som i 1980 vedtok en strategi for å oppnå målet. I denne strategien ble forebygging av selvmord og selvmordsfors $\varnothing \mathrm{k}$ inkludert. Stortinget vedtok en handlingsplan mot selvmord som ble avsluttet i 1999. Deretter har dette arbeidet blitt videref $\varnothing \mathrm{rt}$, og politiske myndigheter har bevilget midler over statsbudsjettet til forskning, undervisning og forebyggende tiltak. I statsbudsjettet for 2005 fra regjeringen Bondevik II satses det videre på tiltak rettet mot barn, unge, voksne og risikogrupper (Helse- og omsorgsdepartementet, 2004). Forskning på selvmord og kompetanseutvikling er også sentrale satsningsområder for Helse- og omsorgsdepartementet i 2005.

\section{Potensial for forebygging}

Hvor stort er selvmord som folkehelseproblem, og hvor er potensialet for forebygging st $\varnothing$ rst? I Norge registreres årlig omkring $550 \mathrm{~d} \varnothing \mathrm{dsfall}$ der sannsynlig d $\varnothing \mathrm{ds}$ årsak var selvmord. Det tilsvarer en hyppighet på omkring 12 tilfeller per 100000 innbyggere per år. Dette mønsteret har vært stabilt i siste 10-årsperiode (19942003). Registerte selvmord i perioden har variert mellom 500 og 600 per år.

Registreringen omfatter personer med fast bosted i Norge, uavhengig av hvor dødsfallet skjedde. Det er tre ganger så mange menn som kvinner som dør i selvmord. De vanligste selvmordsmetodene er hengning/kvelning, skyting og forgiftning. Disse metodene benyttes i til sammen 80 prosent av alle observerte tilfeller (Gjertsen, 2003). Kvinner bruker meget sjelden skyting som dødsmåte. Omtrent 25 prosent av alle skade- og forgiftningstilfeller med dødelig utgang er selvmord. Ulykker er årsak til mellom 70-75 prosent av skaded $\varnothing$ dsfallene, mens drap utgjør 2-3 prosent.
Selvmord står for 1-2 prosent av alle dødsfall. I yngre aldersgrupper utgjør selvmord en relativt stor andel av dødsfallene, og selvmord tar således mange leveår.

Selvmord utgjør en st $\varnothing$ rre andel av d $\varnothing \mathrm{ds}$ fall blant unge i dag sammenlignet med noen tiår tilbake. Dette skyldes i vesentlig grad nedgang i dødelighet av andre dødsårsaker - først og fremt ulykker, samt at dødeligheten i selvmord blant unge er på et høyere nivå enn tidligere.

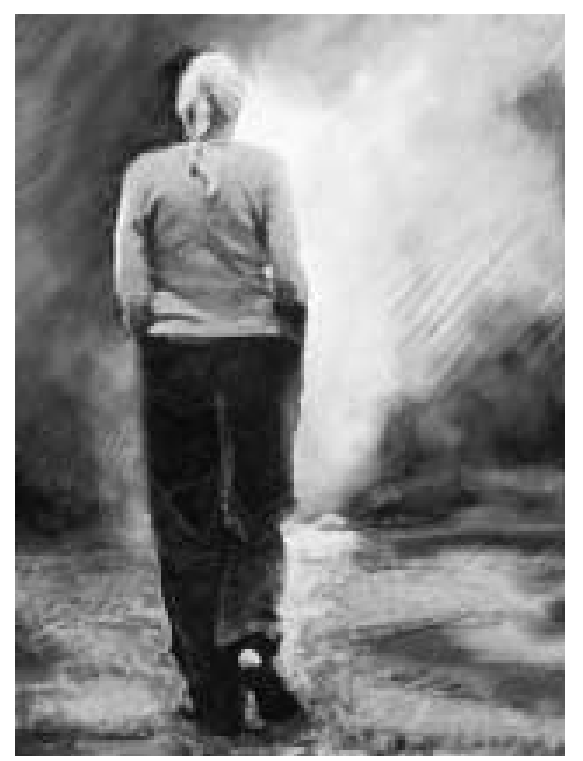

Det er problematisk å bruke andel selvmord av alle d $\varnothing$ dsfall som uttrykk for problemets st $\varnothing$ rrelse og utvikling. Selvmord målt som andelen av alle d $\varnothing$ dsfall kan vise et bilde som er forskjellig fra det bildet raten (selvmord per 100000 innbyggere) viser. Figur 1 viser de offisielle selvmordstallene for unge menn 15-24 år i 2001 og 2003: Andelen $\varnothing$ kte fra i underkant av 22 prosent i 2001 til omtrent 27 prosent i 2003, mens raten viser noe lavere nivå i 2003 sammenlignet med 2001 (henholdsvis 20,6 og 22,1 per 100 000). Antall registrerte selvmord i de to årene var omtrent det samme (61 i 2001 of 58 i 2003). Tilsvarende vil gjelde hvis man bruker andeler i sammenligning mellom geografiske områder. Hvis en andels $\varnothing$ kning feiltolkes som hyppighet (nivå), kan fokus for forebyggende innsats bli misvisende. En situasjon med redusert dødelighet i
Figur 1. Selvmord, menn 15-24 år. Andel og rate. 2001, 2003.

30

25

20

Prosent av dødsfall

25

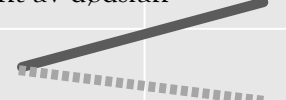

15

10

5

0

2001

2003

Datakilde: www.ssb.no

en befolkning, innebærer at det teoretiske potensial for å hindre fremtidige tilfeller blir mindre. Alternativet som da kan vurderes, er å rette innsats mot deler av befolkningen med en høyere hyppighet. Det kan være spesielle risikogrupper eller populasjoner/områder med mange rapporterte tilfeller. Skal generelle tiltak rettes mot bestemte grupper av befolkningen, må disse ha en viss st $\varnothing$ rrelse tatt i betraktning at selvmord er et relativt sjeldent fenomen. I et lokalsamfunn på 10000 innbyggere kan man forvente ett til to tilfeller i gjennomsnitt per år (med stor årlig variasjon), forutsatt samme hyppighet som har blitt observert i normalbefolkningen de siste årene. Ved identifisering av grupper eller områder med høy hyppighet bør det spørres om den høye hyppigheten uttrykker stabilitet, dvs. ikke kan forklares med tilfeldighet og/eller feilrapportering.

\section{Dødsmåte/metode}

Figur 2 (neste side) gir en oversikt over alle selvmord som har blitt klassifisert og kodet som selvmord i det nasjonale dødsårsaksregisteret i sjuårsperioden

1996-2002 fordelt på metode; i alt 3765 selvmord. Dette omfatter personer som på dødstidspunktet var registrert i folkeregisteret med fast bosted i Norge, uavhengig av hvor d $\varnothing$ dsfallet fant sted. D $\varnothing$ dsfall blant personer med midlertidig opphold 
Figur 2. Registrerte selvmord etter metode (ICD-10 koder), $N=3765.1996-2002$

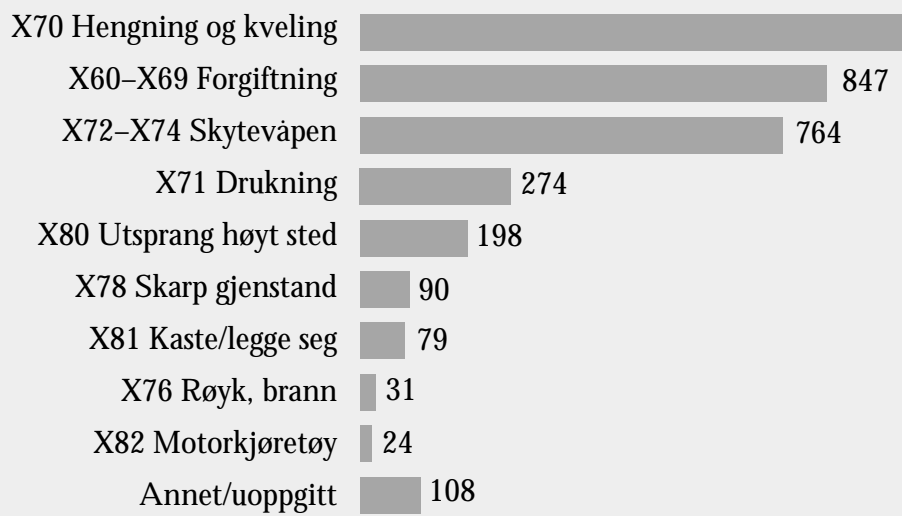

\section{7} 764

\section{4}

198

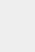

Figur 3. Registrerte selvmord etter kjønn, metode (ICD-10). 1996-2002

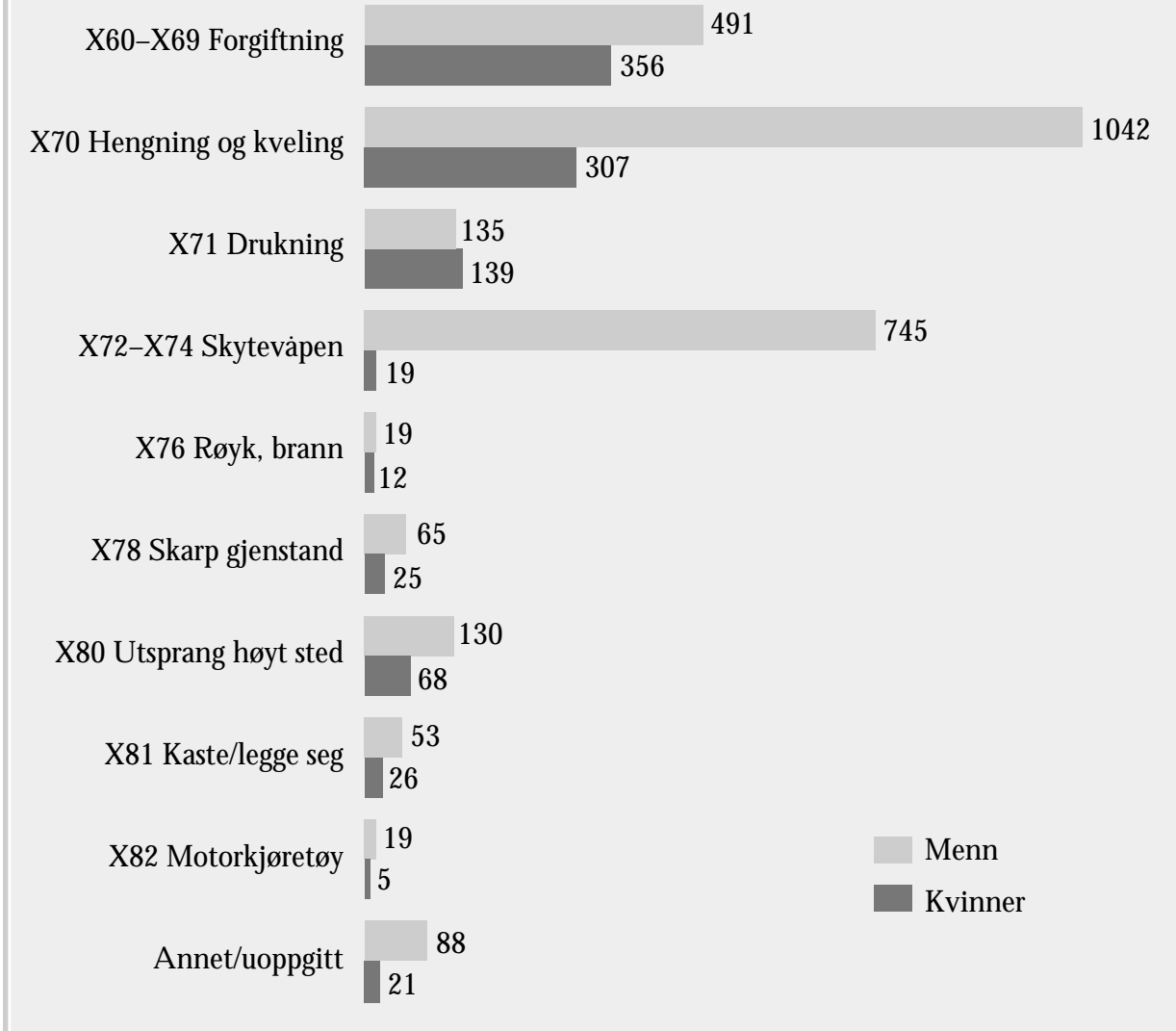

Datakilde: Dødsårsaksregisteret, $\mathrm{N}$ asjonalt folkehel seinstitutt.

i N orge er ikke inkludert. Av de 3765 registrerte tilfellene var 2787 menn og 978 kvinner. De tre vanligste metodene var hengning, forgiftning og skyting som til sammen stod for 79 prosent av alle registerte tilfeller (2960 av 3765). H engning var den mest brukte metoden og stod for 36 prosent, 22 prosent var for- (årlig gjennomsnitt på 27). Disse inkluderer utsprang fra bygning, fjell, bro og andre høye steder. Det er ikke kjent hvor mange av disse som skjedde fra broer. Det som finnes registrert om stedet for handlingen, var at 65 av utsprangene skjedde i og ved hjemmet, 24 på sykehusområder og tre på arbeidsplass. For resten mangler spesifikk informasjon ( 88 skjedde andre steder enn de nevnte, og 18 tilfeller var registrert med sted ukjent). Det teoretiske potensialet for å forebygge selvmord ved sikring av broer utgjør således et begrenset antall årlig. Som det fremgår av figur 3, gjelder tilsvarende for selvmord i trafikken og de tilfeller som skjedde ved at man kastet eller la seg foran gjenstand i bevegelse. I perioden 1996-2002 ble det registrert henholdsvis 24 selvmord hvor motorkjøretøy var brukt som metode, og 79 tilfeller hvor man kastet/la seg foran kjøretøy eller andre gjenstander i bevegelse.

Forebygging av skade og sykdom forutsetter at det er mulig å identifisere årsaker at det foreligger kunnskap om hvilke tiltak som virker, og at tiltakene er etisk forsvarlige. Strategier for å bekjempe alvorlige personskader og død av ulykker, villet egenskade eller selvmord vil bli forskjellige grunnet forskjellige årsaksmønstre. I tillegg kommer det forhold at ulykker og selvmord er vesensforskjellige hva gjelder hendelsens intensjon. Fordi det ligger intensjon bak selvmord og egenskade, vil det være vanskelig å planlegge forebygging av sel vmord og villet egenskade basert på risikofaktorer alene Det kan man lettere gjøre ved forebygging av ulykkesskader (G jertsen, 2003).

Skadeforebyggen de tiltak rettet mot fysiske objekter eller miljøer kan ha positive effekter på forskjellige skadetyper uavhengig av intensjon (ulykker, villet egenskade, selvmord og vold). Eksempler på dette kan være fysisk sikring av broer, områder for forstadsbaner og motorveier, samt fysisk skille mellom motgåen de kjørefelt på veier med høy hastighet. Skadeforebyggen de tiltak som iverksettes med et formål (redusere ulykker) kan således virke forebyggende på andre skadetyper og for eksempel reduserer tilgjengelighet til, og farligh et ved, objekter og steder som anvendes i selvmordshensikt. giftning og 20 prosent skyting. Skyting er den nest vanligste metoden blant menn (27 \%) etter hengning (37\%).

A ndre brukte metoder var drukning (7\%), som var den tredje vanligste metode blant kvinner (figur 3). I sjuårsperioden 1996-2002 ble i underkant av 200 selvmord knyttet til utsprang fra høyt sted 
Begrensning av tilgang til farlige gjenstander og medikamenter er blant de tiltak som Verdenshelseorganisasjon anbefaler for å redusere omfanget av selvmord (W H O , 2001). Det gjelder for eksempel tilgang til skytevåpen/ammunisjon og medikamenter og stoffer med høy toksisk virkning ved overdose/feilbruk. Slik regulering kan ha stor betydning i tilfeller hvor handlingen preges av impulsivitet og er lite planlagt. Resultater fra en nylig publisert undersøkel se i U SA viste at risikoen for å dø av selvmord hjemme var større for menn med skytevåpen i huset, sammenliknet med menn uten våpen $\mathrm{i}$ hjemmet (D ahlberg et al, 2004). Det ble også vist at menn med våpen hjemme hadde høyere risiko for å død i skytesel vmord andre steder sammenlignet med menn uten slike våpen hjemme. Det ble imidlertid ikke påvist forskjeller mellom grupper med forskjellige typer våpen, antall våpen eller hvordan våpen ble oppbevart i hjemmet. Et annet forhold er hva som påvirker overgang til andre metoder ved regulering eller fjerning av et middel. Endringer i metoder kan ha alvorlige konsekvenser dersom det innebærer overgang fra mer usikre til farligere metoder som for eksempel hengning.

\section{God kvalitet nødvendig}

G od beskrivelse av et fenomensutbredelse og utvikling, samt analyser av risikofaktorer og årsaksforhold forutsetter at de data som brukes er til å stole på. Størrel sen på det teoretiske potensial for forebygging av en bestemt tilstand i en populasjon baseres på informasjon som fremkommer i deskriptiv forskning og nasjonal statistikk. I en kommentarartikkel i tidsskriftet til den internasjonale foreningen for selvmordsforebygging, C risis, diskuterte professor D avid Lester (2002) betydningen av pålitelige selvmordsdata for forskning, prioritering og forebygging. Lester tar spesielt opp forholdene i Storbritannia hvor registreringen baseres på rettslige vedtak (coronor-systemet hvor en embetsmann sammen med en oppnevnt komité etterforsker og tar stilling til hva som var den sannsynlige årsak til unaturlige eller mistenkelige dødsfall) . I artikkelen refereres det til fem nyere undersøkelser om rapportering og koding av selvmord i England. R esultater viste en underestimering av selvmord varierende mellom 24 og 42 prosent sammenliknet med den offisielle registreringen. Lester argumenterer så for at en slik feilklassifisering har alvorlige implikasjoner for forskning og forebyggende arbeid: For eksempel hvis man ønsker å finne ut om et bestemt program innen psykisk helse påvirker dødelighet i selvmord, så forutsetter det tilgang til sikker kunnskap om dødsårsak ( selvmord). Lester viser også til andre studier fra England og W ales som tyder på visse systematiske skjevheter i den britiske registreringen.

Resultater fra de enkelte undersøkelser Lester viser til, kan ikke uten videre overføres til forhold i andre land bl.a. grunnet det spesielle rapporteringssystemet i England. Derimot vil god kvalitet på registre ringen av selvmord og andre dødsårsaker i nasjonale dødsårsaksregistre være avgjørende viktig for forskning og analyseformål.

God kvalitet på rutinedata som brukes som grunnlag for beslutninger om tiltak, for eksempel på områdene ulykker og selvmord, er viktig i mange faser i den politiske beslutningsprosess som innebærer å:

- identifisere problemet

- vurdere relevant informasjon, og prioritere

- sette ett eller flere mål

- velge mellom flere mulige løsninger på problemet

- bestemme løsning eller strategi

- vurdere konsekvenser av valgt løsning eller strategi

- vurdere eller evaluere resultatet. (Lwanga et al, 1999)

Per i dag mangler det nasjonal statistikk over tilfeller av villet egenskade som har medført medisinsk sykehusbehandling. $\mathrm{G}$ runnen til det er manglende kvalitetssikring av lokal registrering av den ytre skadeårsak. Informasjon om skadens ytre årsak skal brukes, som tilleggskode til informasjon om skadens natur, i pasientregistreringen ved norske sykehus. Dette ble gjort gjeldende fra 1999 ved overgang til norsk utgave av ICD-10 i somatikken. $\mathrm{N}$ år det gjelder kvaliteten på registrering av selvmord i Dødsårsaksregisteret, har Folkehel seinstituttet igangsatt et prosjekt for å vurdere kvalitet og foreslå tiltak som kan utvikle og forbedre kvaliteten.

Folkehelseinstituttet overtok ansvaret for dette registeret fra 2002. Det har lenge vært kjent at kvaliteten i dødsårsaksregistreringen ikke er så god som den burde ( $N$ ordrum, 2004). Den sterke økning de siste årene i bruk av symptomer og ubestemte tilstander som dødsårsak kan tyde på svekket kvalitet på registreringen, med konsekvenser på selvmordsstatistikken. N orge har gode forutsetninger til å utvikle dette registeret slik at det kan oppfylle de mange formål registeret skal betjene slik det fremkommer i helseregisterloven med forskrift.

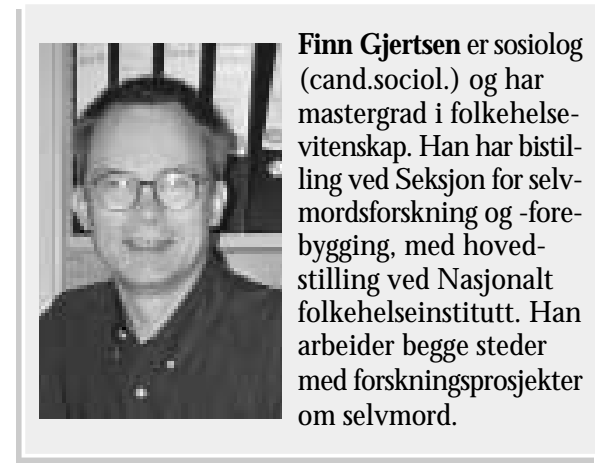

\section{Referanser}

Dahl berg LL, I keda RM , Kresnow M -j. (2004). $G$ uns in the home and risk of violent death in the home: findings from a national study. A $\mathrm{m}$ J Epidemiol, 160, 929-936.

G jertsen $F$ (2003). U tviklingstendenser i selvmord. D atagrunnlag, kvalitet og sammenlignbarhet. M PH 2003:35. G öteborg: N ordiska högskolan för folkhälsovetenskap.

H else- og omsorgsdepartementet (2004) St.prp. nr. 1 (2004-2005) for budsjetterminen 2005. O slo: Statens forval tningstjeneste.

Lester, D (2002). T he scientific study of suicide requires accurate data. C risis, 23 (3), 133-134.

Lwanga S K, Tye C - Y, A yeni O (1999). Teaching health statistics. Second edition. G eneva: W orld $\mathrm{H}$ ealth $\mathrm{O}$ rganization.

N ordrum, Ivar Skjåk. (2004). H va var dødsårsaken? Leder i Tidsskr N or Lægeforen, 12, 1618.

W HO (2001). T he World H ealth R eport 2001. Mental health: new understanding, new hope. $\mathrm{G}$ eneva: W orld Health O rganization. 